\title{
Physicochemical properties of extrudates from white yam and bambara nut blends
}

\author{
O.B. Oluwole ${ }^{1}$, A.A. Olapade ${ }^{2 *}$, S.O. Awonorin ${ }^{3}$, and F.O. Henshaw ${ }^{3}$ \\ ${ }^{1}$ Federal Institute of Industrial Research, Oshodi, Lagos, Nigeria \\ ${ }^{2}$ Department of Food Technology, University of Ibadan, Ibadan, Oyo State, Nigeria \\ ${ }^{3}$ Department of Food Science and Technology, University of Agriculture, Abeokuta, Ogun State, Nigeria
}

Received September 4, 2011; accepted February 1, 2012

\begin{abstract}
A b stract. This study was conducted to investigate effects of extrusion conditions on physicochemical properties of blend of yam and bambara nut flours. A blend of white yam grit $(750 \mu \mathrm{m})$ and Bambara nut flour $(500 \mu \mathrm{m})$ in a ratio of $4: 1$, respectively was extrusion cooked at varying screw speeds $50-70$ r.p.m., feed moisture $12.5-17.5 \%$ (dry basis) and barrel temperatures $130-150^{\circ} \mathrm{C}$. The extrusion variables employed included barrel temperature, screw speed, and feed moisture content, while the physicochemical properties of the extrudates investigated were the expansion ratio, bulk density, and trypsin inhibition activity. The results revealed that all the extrusion variables had significant effects $(p<0.05)$ on the product properties considered in this study. The expansion ratio values ranged $1.55-2.06$, bulk density values ranged $0.76-$ $0.94 \mathrm{~g} \mathrm{~cm}^{-3}$, while trypsin inhibition activities were $1.01-8.08 \mathrm{mg}$ $100 \mathrm{~g}^{-1}$ sample.

$\mathrm{K}$ e y w o r d s: yam-bambara blend, extrusion cooking, physicochemical properties
\end{abstract}

\section{INTRODUCTION}

Extrusion cooking has been used as an important technique for modification and manufacture of a wide variety of traditional and novel foods and food blends (Jisha et al., 2010; Nwabueze et al., 2007; Oluwole and Olapade, 2011; Sobota and Rzedzicki, 2009). Expanded snack foods, readyto-eat cereals and dry pet foods are manufactured from cereals and starches by high temperature short time extrusion cooking (Marcos et al., 2008; Njoki and Faller, 2001). The elevated pressure and high temperature applied during the process result in altered physical and chemical properties of the extruded products thereby modifying the functional properties of the food blend (Iwe and Ngoddy, 2000). Nutritional effects of processing however depend on factors including type of extruder, process parameters. and screw configuration (Iwe and Ngoddy, 2000; Zarzycki et al., 2010).
White yam (Dioscorea rotundata) is a good source of carbohydrates, vitamins and minerals, as well as some essential amino acids (Ugwu, 2009). Yam is traditionally eaten in Nigeria as fried yam slices, cooked or boiled or even eaten in roasted forms. It is also processed into flour and cooked as a stiff porridge called 'amala' or processed into instant pounded yam flour usually consumed in the some parts of Nigeria. Bambara nut (Vigna subterranean) is an indigenous African grain legume and is one of the more important crops grown on the African continent (Abu-Salem and AbouArab, 2011). It contains about $24 \%$ protein with a good balance of the essential amino acids and relatively high proportions of lysine (6-8\%) and methionine (1-3\%). The major component of the bean is carbohydrate, mainly starch, which is up to $50 \%$. The minor components in these beans include minerals, vitamins and antinutritional factors such as trypsin inhibitors and polyphenols (Eltayeb et al., 2011).

In developing countries such as Nigeria, starch-based foods are the major staples and have resulted in protein energy malnutrition in adults and infants. However, the utilization of locally grown crops for the production of nutritious convenient recipes in lesser developed countries (LDCS) has been seriously stressed by international agencies as a most suitable channel for addressing the deepening world food problem (Wolfe, 1992). Consequently, the development of ready-to-eat extruded food products using a combination of white yam and white Bambara nut could serve as a means of alleviating hunger among the populace particularly in the lesser developed countries.

Several authors have reported on extrusion cooking of root and tuber crops (Budi and Jenshinn, 2009; Iwe and Ngoddy, 2000; Suknark et al., 1999). There is however dearth of information on extrusion cooking of white yam or 
white yam in combination with bambara nut. It was the objective of this study therefore to determine the effect of some selected process variables of screw speed $(S S)$, barrel temperature $(B T)$ and feed moisture of extrusion cooking on some desirable quality attributes in the ready-to-eat extruded yam-bambara blends.

\section{MATERIALS AND METHODS}

White yam and cream coloured bambara nut were the major raw materials employed in this study. White yam tubers were obtained from National Root Crop Research Institute, Umudike, Abia State, Nigeria, while bambara nut was obtained from Mile 12 market in Lagos, Nigeria. The yam tubers (Dioscorea rotundata) used in this study were subjected to some preliminary operations such as peeling, washing, slicing ( $5 \mathrm{~mm}$ thick), parboiling at $70^{\circ} \mathrm{C}$ for $20 \mathrm{~min}$ and drying at $60^{\circ} \mathrm{C}$ in a tray drier (model 1999 , Germany) for $8 \mathrm{~h}$. The dried yam slices were milled into grits $(750 \mu \mathrm{m})$ using a Hammer mill (FIIRO model 1997, Nigeria). Bambara nut was soaked in excess water at room temperature $\left(30 \pm 2^{\circ} \mathrm{C}\right)$ for $8 \mathrm{~h}$ followed by manual dehulling, then drying at $60^{\circ} \mathrm{C}$ for $8 \mathrm{~h}$ and milling into flour $(500 \mu \mathrm{m})$ using the hammer mill. The samples were sealed in low density polyethylene bags and stored at $4^{\circ} \mathrm{C}$ for subsequent use.

Yam grits and bambara flour at a ratio of $4: 1(\mathrm{w} / \mathrm{w})$ was prepared and thoroughly blended together. The moisture content of the samples was determined using an oven drying method (AOAC, 1995). A Box behnken experimental design was employed to determine the effect of selected extrusion variables of barrel temperature $(B T)$, screw speed $(S S)$, and feed moisture content $(F M)$ on the extrudate parameters of the expansion ratio $(E R)$, bulk density $(B D)$, and trypsin inhibition activity $(T I A)$. Extrusion variables were all tested at three levels $(-1$ to +1$)$. The moisture content of the blend was adjusted to the desired feed moisture content by addition of an amount of distilled water calculated using the Eq. (1) of Oluwole and Olapade (2011):

$$
Q=A(M f-M i) /(1+M i),
$$

where: $A$ - initial mass of the sample $(\mathrm{kg}), M i$ - initial fraction of moisture content of the blend (db), $M f$-desired fraction of moisture content of the blend (db), $Q$ - mass of water to be added to the sample $(\mathrm{kg})$.

The mixtures were packaged and allowed to equilibrate inside low density polyethylene bags for $4 \mathrm{~h}$ before extrusion cooking. A single screw extruder (Komet, 1993 model, Germany) with $30 \mathrm{~cm}$ length, $10 \mathrm{~cm}$ diameter and die opening of $8 \mathrm{~mm}$ was used in this study. Extrusion cooking of the mixtures was carried out as shown in transformed matrix (Table 1). For each run, the extruder temperature was stabilized using $8 \mathrm{~kg}$ soybean grits. At the steady state for each run, the sample was collected inside open stainless steel pan, allowed to cool then packaged inside low density polyethylene bags and stored under refrigeration $\left(4^{\circ} \mathrm{C}\right)$.
The expansion ratio was determined by measuring the diameter of extrudates using a Venier caliper (Multitoyo, Japan). The expansion ratio was expressed as the ratio of the extrudate diameter to the diameter of the extruder die opening. Bulk density was expressed as the mass/volume ratio of extrudates ground to pass through a $250 \mu \mathrm{m}$ sieve. One hundred gram of the sample was weighed into a $250 \mathrm{ml}$ measuring cylinder. Both the cylinder and the content were gently tapped 10 times against palm of hand and the volume occupied by the content was noted. The loose density was determined without tapping the measuring cylinder. Each treatment was done in triplicate. Trypsin inhibition activity was determined in the Bambara nut, white yam and extrudates using the procedure established by previous workers (Kakade et al., 1974).

\section{RESULTS AND DISCUSSION}

The results of the extrudates parameters investigated in this study are presented in Table 1 . The expansion ratio values for the extrudates of yam-bambara varied from 1.50 to 2.06 with the mean value of $1.85 \pm 0.06$. The mathematical model for estimating ER is presented in Eq. (2). The value of $\mathrm{R}^{2}$ for the model was 0.95 , which is an indicative that the model will predict the values of $E R$ provided the values of variables were within the studied range in this study:

$$
\begin{gathered}
E R=2.05-0.06 B T+0.019 S S+0.044 F M-0.088 B T S S \\
-0.073 B T F M+0.09 S S F M-0.24 B T 2+0.036 S S 2 \\
-0.21 F M 2 \quad\left(\mathrm{R}^{2}=0.95\right) .
\end{gathered}
$$

The significant model terms are barrel temperature, interaction between barrel temperature and screw speed, screw speed and feed moisture and the quadratic effect of barrel temperature and feed moisture content. These significances are revealed in Fig. 1. Figure 1a shows that ER increased with the increase in screw speed, while it also increased with the increase in barrel temperature up to a point when it started decreasing as a result of the quadratic effect of barrel temperature on the expansion ratio. Figure $1 \mathrm{~b}$ presents the effect of a combination of the feed moisture content and screw speed on $E R$ of extrudates of the yam-bambara blend. It was observed in this case that $E R$ increased with the increase in $S S$. Also the quadratic effect of FM on ER was conspicuously revealed in the response surface plot. The expansion ratio and bulk density of extruded food products have been reported as the most useful indices of quality in expanded food products. High barrel temperatures have also been reported to favour a high expansion ratio in extruded food products (Thymi et al., 2005).

It appears that at higher screw speeds, the feed blend was more properly homogenized and that favoured the production of extrudates of a higher expansion ratio than at lower screw speeds of 50 and 60 r.p.m. Similar observations have been reported in some extruded rice, corn products, and sweet potato - soya mixtures (Iwe, 1998; Iwe and Ngoddy, 2000). 
T a b l e 1. Matrix transformation of the experimental design runs and extrusion conditions

\begin{tabular}{|c|c|c|c|c|c|c|c|c|c|}
\hline \multirow{2}{*}{$\begin{array}{l}\text { Experimental } \\
\text { run }\end{array}$} & \multicolumn{3}{|c|}{ Variables code } & \multicolumn{3}{|c|}{ Variables actual value } & \multicolumn{3}{|c|}{ Response* } \\
\hline & $B T$ & $S S$ & $F M$ & $\begin{array}{l}B T \\
\left({ }^{\circ} \mathrm{C}\right)\end{array}$ & $\begin{array}{c}S S \\
\text { (r.p.m.) }\end{array}$ & $\begin{array}{l}F M \\
(\%)\end{array}$ & $E R$ & $\begin{array}{c}B D \\
\left(\mathrm{~g} \mathrm{ml}^{-1}\right)\end{array}$ & $\begin{array}{c}\text { TIA } \\
\left(\mathrm{mg} 100 \mathrm{~g}^{-1}\right)\end{array}$ \\
\hline 1 & 0 & 1 & 1 & 140 & 70 & 17.5 & $2.06 \pm 0.12$ & $0.78 \pm 0.02$ & $6.77 \pm 0.23$ \\
\hline 2 & -1 & -1 & 0 & 130 & 50 & 15.0 & $1.79 \pm 0.13$ & $0.91 \pm 0.04$ & $6.77 \pm 0.54$ \\
\hline 3 & 0 & 0 & 0 & 140 & 60 & 15.0 & $2.00 \pm 0.11$ & $0.82 \pm 0.03$ & $6.39 \pm 0.43$ \\
\hline 4 & 0 & 0 & 0 & 140 & 60 & 15.0 & $2.01 \pm 0.14$ & $0.81 \pm 0.03$ & $6.30 \pm 0.65$ \\
\hline 5 & 0 & 0 & 0 & 140 & 60 & 15.0 & $2.00 \pm 0.13$ & $0.80 \pm 0.04$ & $6.25 \pm 0.40$ \\
\hline 6 & 0 & 0 & 0 & 140 & 60 & 15.0 & $2.02 \pm 0.11$ & $0.82 \pm 0.03$ & $6.35 \pm 0.32$ \\
\hline 7 & +1 & -1 & 0 & 150 & 50 & 15.0 & $1.90 \pm 0.13$ & $0.76 \pm 0.05$ & $5.87 \pm 0.43$ \\
\hline 8 & +1 & 0 & -1 & 150 & 60 & 12.5 & $1.50 \pm 0.10$ & $0.74 \pm 0.10$ & $1.01 \pm 0.23$ \\
\hline 9 & -1 & +1 & 0 & 130 & 70 & 15.0 & $1.95 \pm 0.07$ & $0.84 \pm 0.07$ & $8.08 \pm 0.25$ \\
\hline 10 & +1 & 0 & +1 & 150 & 60 & 17.5 & $1.50 \pm 0.06$ & $0.78 \pm 0.05$ & $1.67 \pm 0.43$ \\
\hline 11 & 0 & -1 & +1 & 140 & 50 & 17.5 & $1.85 \pm 0.16$ & $0.86 \pm 0.06$ & $4.90 \pm 0.33$ \\
\hline 12 & 0 & +1 & -1 & 140 & 70 & 12.5 & $1.81 \pm 0.06$ & $0.94 \pm 0.07$ & $7.82 \pm 0.76$ \\
\hline 13 & +1 & +1 & 0 & 150 & 70 & 15.0 & $1.73 \pm 0.16$ & $0.77 \pm 0.05$ & $3.46 \pm 0.49$ \\
\hline 14 & 0 & -1 & -1 & 140 & 50 & 12.5 & $1.91 \pm 0.07$ & $0.90 \pm 0.06$ & $6.70 \pm 0.52$ \\
\hline 15 & -1 & 0 & -1 & 130 & 60 & 12.5 & $1.55 \pm 0.15$ & $0.86 \pm 0.04$ & $6.60 \pm 0.55$ \\
\hline 16 & -1 & 0 & +1 & 130 & 60 & 17.5 & $1.84 \pm 0.07$ & $0.84 \pm 0.03$ & $6.79 \pm 0.71$ \\
\hline 17 & 0 & 0 & 0 & 140 & 60 & 15.0 & $2.03 \pm 0.11$ & $0.82 \pm 0.04$ & $6.31 \pm 0.87$ \\
\hline Means & & & & & & & $1.85 \pm 0.06$ & $0.83 \pm 0.04$ & $5.79 \pm 1.00$ \\
\hline
\end{tabular}

*Means of three replicates. $B T$ - barrel temperature, $S S$ - screw speed, $F M$ - feed moisture content, $E R$ - expansion ratio, $B D$ - bulk density, $E M$ - extrudate moisture content, $T I A$ - trypsin inhibition activity.
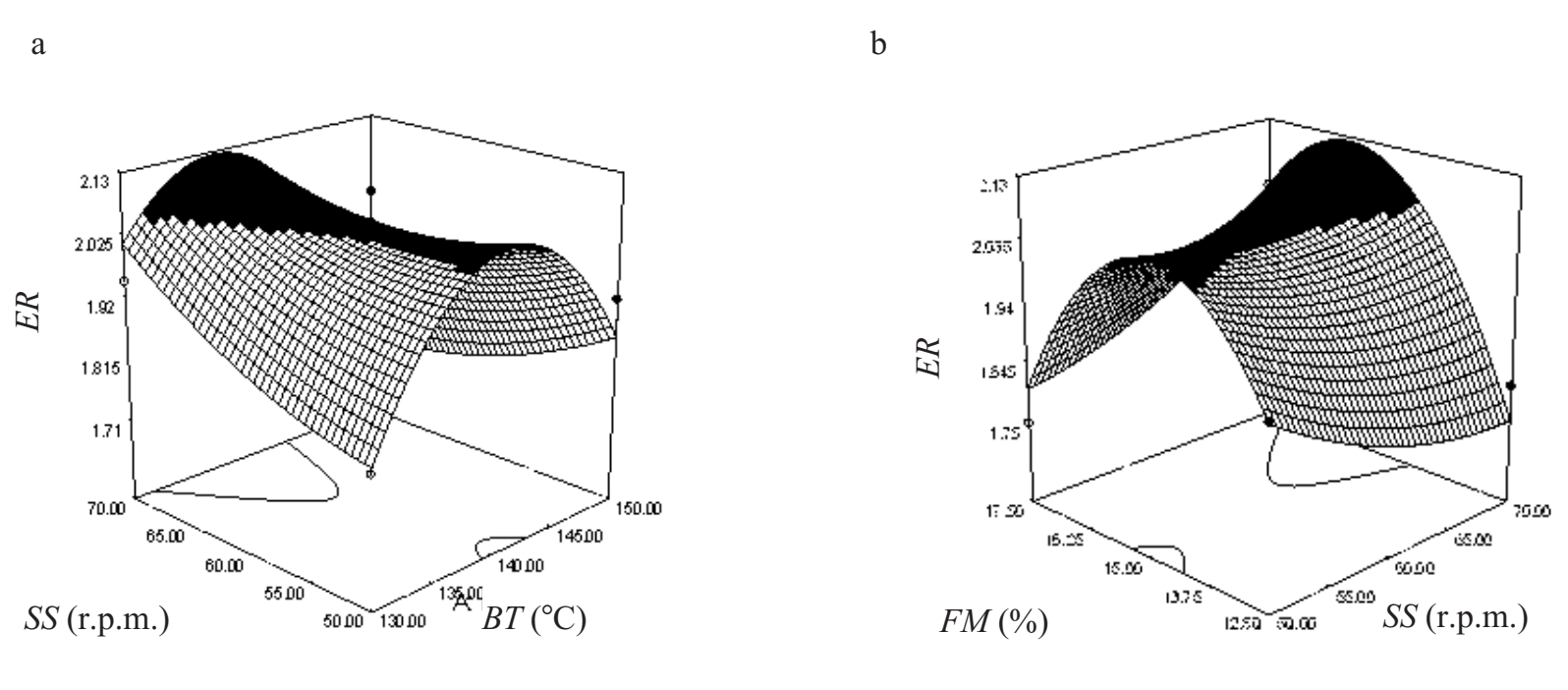

Fig. 1. Response surface of $E R$ as a function of: $\mathrm{a}-B T$ and $S S, \mathrm{~b}-F M$ and $S S$. 
The bulk density values observed in this study were $0.74-0.94 \mathrm{~g} \mathrm{~cm}^{-3}$ with mean value of $0.83 \pm 0.04 \mathrm{~g} \mathrm{~cm}^{-3}$. The model for determination of value of the $\mathrm{BD}$ is given in Eq. (3). The value of $\mathrm{R}^{2}$ for the model was 0.95 , which is an indicative that the model will predict the values of bulk density with a higher degree of accuracy provided the values of variables were within the studied range in this study. The only significant term in the model is barrel temperature, which shows that the bulk density of extrudate is only significantly affected by barrel temperature during extrusion cooking operation of yam-bambara blend:

$$
\begin{gathered}
B D=0.82-0.05 B T-0.013 S S-0.022 F M+0.02 B T S S+ \\
0.015 B T F M 0.03 S S F M-0.032 B T 2+0.033 S S 20.017 F M 2 \\
\left(\mathrm{R}^{2}=0.82\right) .
\end{gathered}
$$

Visual observations of the effects of the extrusion variables of $B T, S S$ and $F M$ on bulk density are presented in Fig. 2a, b. The extrusion variables of screw speed and feed moisture, though not significantly ( $p>0.05$ ), were also found to have effects on the bulk density of the extrudates. Bulk density had been reported to be one of the most important indices of quality in extruded food products (Osundahunsi, 2006). The lower the bulk density of the extrudates, the higher the expansion ratio of the extrudates as they have been reported to be negatively correlated (Iwe, 1998; Iwe and Ngoddy, 2000; Nwabueze, 2008). High barrel temperatures of up to $140^{\circ} \mathrm{C}$ have been found to reduce density of an expanded wheat snack (Thymi et al., 2005), hence the lower density values of the extrudates at higher barrel temperatures.

The values of TIA varied considerably for the extrudates of yam-bambara nut blend with a mean value of 5.97 $1.0 \mathrm{mg} 100 \mathrm{~g}^{-1}$ sample compared to 5.48 and $12.3 \%$ values

a

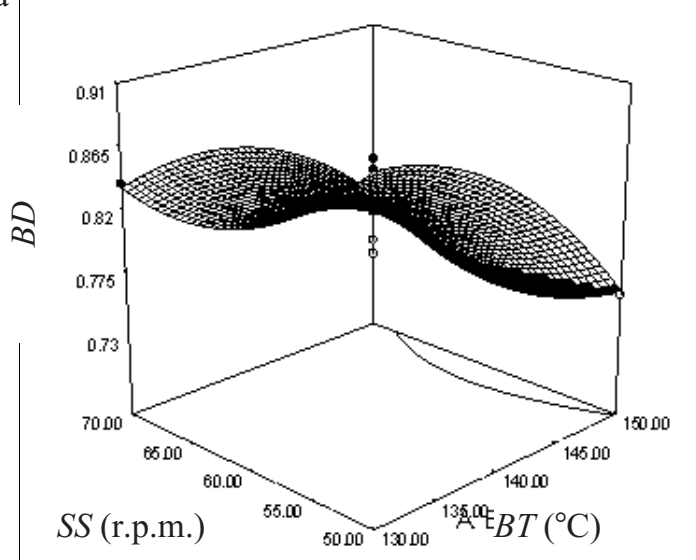

for yam grit and bambara flour respectively used in this study. The highest value of $8.08 \mathrm{mg} 100 \mathrm{~g}^{-1}$ was obtained at $130^{\circ} \mathrm{C}, 70$ r.p.m. and $15 \%$ for barrel temperature, screw speed and feed moisture content respectively. The least va-

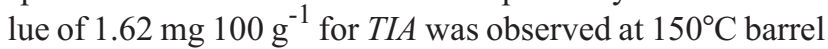
temperature, 60 r.p.m. screw speed and $17.5 \%$ feed moisture content. Equation (4) expresses a model for prediction of TIA with the coefficient of prediction equaled 0.87 . In this case, both linear and quadratic effects of barrel temperature were significant terms of the model:

$$
\begin{gathered}
T I A=6.40-2.03 B T+0.23 S S-0.26 F M-0.93 B T S S+ \\
0.13 B T F M+0.19 S S F M-1.44 B T 2+1.1 S S 2-0.95 F M 2 \\
\left(\mathrm{R}^{2}=0.87\right) .
\end{gathered}
$$

Generally there was a reduction in the trypsin inhibitor content in the extrudates as the barrel temperature increased from 130 to $150^{\circ} \mathrm{C}$ at the screw speed ftom 50 to 70 r.p.m. (Fig. 3). Also, at all the feed moisture levels ie $12.5 \%$ to $17.5 \%$ employed in this study, there was a drastic reduction of trypsin inhibition activity as the barrel temperature increased from 140 to $150^{\circ} \mathrm{C}$ while keeping the other extrusion condition constant $i e$ screw speed of 70 r.p.m. (Fig. 4). Similar results were reported for trypsin inhibition activity of extruded soy-potato (Iwe and Ngoddy, 2000) and extruded acha/ soybean (Anuonye et al., 2007). It was reported that heat generally played a significant role in the reducing trypsin inhibitor in any food product (Wanasundara and Ravindran, 1992). The results obtained were in agreement with the observation of Anuonye et al. (2007), who reported for acha/ soybean that extrusion cooking reduced TIA by about 70$97 \%$ with feed moisture and barrel temperature having the greatest influence. Nwabueze et al. (2007) also reported that extrusion cooking resulted in reduction in TIA of breadfruit based spaghetti type.

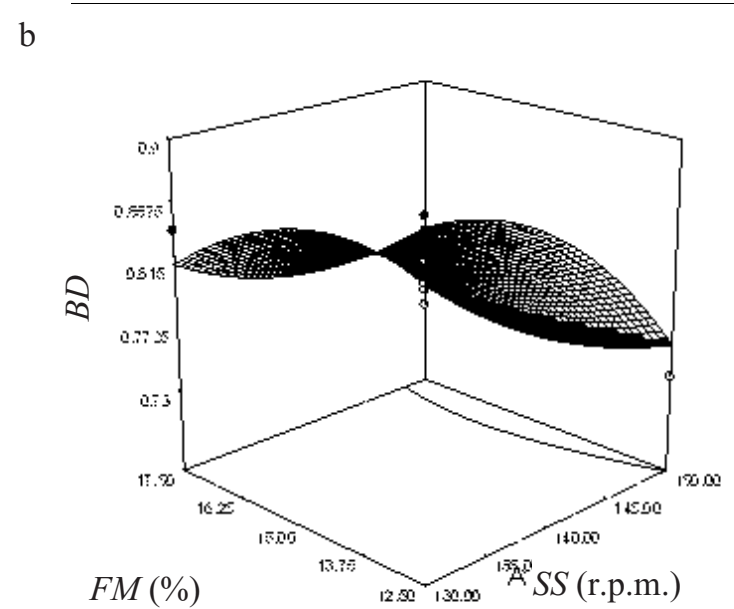

Fig. 2. Response surface of bulk density as a function of barrel temperature and: a - screw speed, b - feed moisture content. 


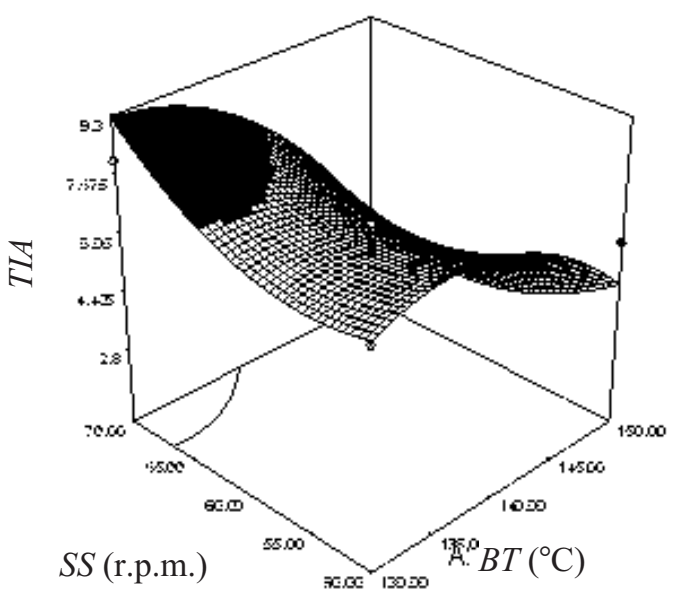

Fig. 3. Response surface of trypsin inhibition activity of extrudate as a function of barrel temperature and screw speed.

\section{CONCLUSIONS}

1. It is possible to prepare complementary food from a yam and bambara nut flour.

2. The values of the expansion ratio of extrudates ranged from 1.50 to 2.06 and it was significantly affected by extrusion variables of barrel temperature and interactions among the variables.

3 . The bulk density values for the extrudates ranged from 0.74 to $0.94 \mathrm{~g} \mathrm{~cm}^{-3}$ with mean value of $0.03 \mathrm{~g} \mathrm{~cm}^{-3}$ and it increased with the increase in barrel temperature.

4. Trypsin inhibition activity of the extrudates was significantly reduced by the increase in barrel temperature used in this study.

\section{REFERENCES}

Abu-Salam F.M. and Abou-Arab A.A., 2011. Effect of supplementation of bambara groundnut (Vigna subterranean L.) flour on the quality of biscuits. African J. Food Sci., 5(7), 376-383.

Anuonye J.C., Badifu G.I.O., and Inyang C.U., 2007. Protein digestibility index and trypsin inhibitor activity of extruded blends of acha/soybean: A response surface analysis. Am. J. Food Tech., 2(6), 502-511.

AOAC, 1995. Official methods of analysis. Association of Official Analytical Chemists, Washington, DC, USA.

Budi N. and Jenshinn L., 2009. Effect of process variables on the physical properties of taro extrudate. World J. Dairy Food Sci., 4(2), 154-159.

Eltayeb A.S.M., Ali A.O., Abuo-Arab A.A., and Abu-Salam F.M., 2011. Chemical composition and functional properties of flour and protein isolate extracted from bambara groundnut (Vigna subterranean). African J. Food Sci., 5(2), 82-90.

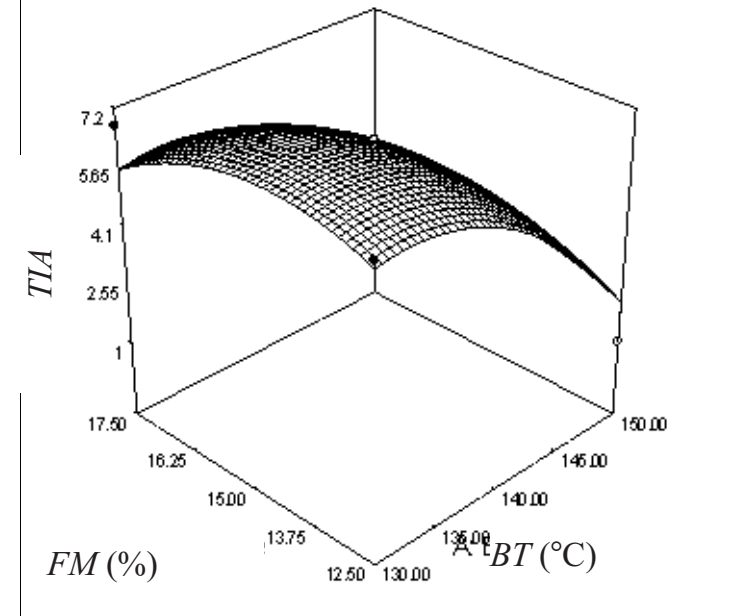

Fig. 4. Response surface of extrudate trypsin inhibition activity as a function of barrel temperature and feed moisture content.

Iwe M.O., 1998. Effect of extrusion cooking on functional properties of mixtures of full fat soy and sweet potato. Plant Foods Human Nutr., 53(1), 37-46.

Iwe M.O. and Ngoddy P.O., 2000. Effect of extrusion on trypsin inhibitor contents of soy-sweet potato. J. Food Proc. Pres., 24, 453-463.

Jisha S., Sheriff J.T., and Padmaja G., 2010. Nutritional, functional and physical properties of extrudates from blends of cassava flour with cereal and legume flours. Int. J. Food Prop., 13(5), 1002-1011.

Kakade M.L., Rackis J.J., Mcghee J.E., and Puski G., 1974. Determination of trypsin inhibitor activity of soy products: A collaborative analysis of an improved procedure. Cereal Chem., 51, 376-382.

Marcos J.F., Antonion G.S., Murillo F.J., Dejani L.A., and Jos L.R.A., 2008. Effect of extrusion cooking in total carotenoid content on cream and orange flesh sweet potato cultivars. Hort. Bricultura Brasileira, http://dx.doi.org/10.1590/S010205362008000100022

Njoki P. and Faller J.F., 2001. Development of an extruded plantain/ corn/soy weaning food. Int. J. Food Sci. Tech., 36(4), 415-423.

Nwabueze T.U., 2008. Growth performance of rats fed with raw and extruded African breadfruit based complementary diet. A response surface analysis. J. Sci. Food Agric., 88(3), 522-528.

Nwabueze T.U., Iwe M.O., and Akobundu E.N.T., 2007. Unit operations and analyses for African breadfruit based spaghettitype products at extreme process combinations. J. Food Tech., 5(1), 87-94.

Oluwole O.B. and Olapade A.A., 2011. Effect of extrusion cooking of white yam and bambara-nut blend on some selected extrudate parameters. Food Nutr. Sci., 2(6), 599-605.

Osundahunsi O.F., 2006. Functional properties of extruded soybean with plantain flour blends. J. Food, Agric. Envir., 4(1), 57-60. 
Sobota A. and Rzedzicki Z., 2009. Effect of the extrusion process of corn semolina and pea hulls blends on chemical composition and selected physical properties of the extrudate. Int. Agrophysics, 23, 67-79.

Suknark K., Phillips R.D., and Huag Y.-W., 1999. Tapioca-fish and tapioca-peanut snacks by twin screw extruder and deep fat frying. J. Food Sci., 64(2), 303-308.

Thymi S., Krokida M.K., Pappa A., and Maroulis Z.B., 2005. Structural properties of extruded corn starch. J. Food Eng., $68,519-526$
Ugwu F.M., 2009. The potentials of roots and tubers as weaning foods. Pakistan J. Nut., 8(10), 1701-1705.

Wanasundara J.P.D. and Ravindran G., 1992. Effect of cooking on the nutrient and anti nutrient content of yam tubers (Dioscorea alata and Dioscorea esculenta). Food Chem., 45, 247-250.

Wolfe J.A. (Ed.), 1992. Sweet potato: An Untapped Food Resource. Cambridge University Press, Cambridge, UK.

Zarzycki P., Rzedzicki Z., and Blaszczak W., 2010. Application of oat whole-meal and protein components as modifiers of extrudates microstructure. Int. Agrophys., 24, 397-406. 